\title{
WHO'S THAT LYING IN MY COFFIN? AN IMPOSTER EXPOSED BY ${ }^{14} \mathrm{C}$ DATING
}

\author{
Karin Sowada ${ }^{1}$ Geraldine E Jacobsen ${ }^{2} \cdot$ Fiona Bertuch $^{2} \bullet$ Tim Palmer $^{3} \bullet$ Andrew Jenkinson ${ }^{2}$ \\ ABSTRACT. In the 19th and early 20th centuries, many museums acquired Egyptian coffins containing mummies from pri- \\ vate donors who bought them from dealers in Egypt. Owing to the unknown context of such acquisitions, it cannot be assumed \\ that the mummified individual inside the coffin is the same person named on it. Radiocarbon dating is a key diagnostic test, \\ within the framework of a multidisciplinary study, to help resolve this question. The dating of an adult mummy in the Nichol- \\ son Museum at the University of Sydney was therefore checked using ${ }^{14} \mathrm{C}$ dating. For over $150 \mathrm{yr}$, mummy NM R28.2 was \\ identified as Padiashaikhet as per his coffin, dated to the 25 th Dynasty, about $725-700$ BC. ${ }^{14} \mathrm{C}$ results from samples of linen \\ wrappings revealed that the mummy was an unknown individual from the Roman period, cal AD 68-129. The mummification \\ technique can now be understood within its correct historical context.
}

\section{INTRODUCTION}

For some time, it has been recognized that certain mummies in coffins displayed in museum collections may not belong together (Dawson and Gray 1968:xii; Strouhal cited in Cockburn et al. 1975: 1158; Sowada et al. 2005). With the scientific study of Egyptian mummies having accelerated over the last few years (Aufderheide 2003; David 2008), the question of the correct dating of a mummy and the historical interpretation of the embalming techniques remain. Unless the name of the individual written on the linen wrappings is the same as the name on the coffin (J Taylor, personal communication, 1999; e.g. Spencer 2002:54), questions must remain over the precise identity of a mummy obtained from undocumented private sources, particularly if the coffin was already open on acquisition.

One method of resolving this problem is through radiocarbon dating a textile, or more preferably, a human tissue sample from the mummy, to check if the date of the mummy is consistent with the date of the coffin. This proposition was tested by ${ }^{14} \mathrm{C}$ dating linen samples from a mummy held in the Nicholson Museum at the University of Sydney, Australia. Since 1858, mummy NM R28.2 was believed to belong to the coffin in which it was acquired. ${ }^{14} \mathrm{C}$ dating revealed a major discrepancy between the date of the mummy and the coffin, showing that they do not belong together.

\section{THE PROBLEM OF MUMMIES IN MUSEUM COLLECTIONS}

While large museums often acquired their material directly from excavations, many smaller museums obtained at least part (or all) of their collections from private sources (Ikram and Dodson 1998: 86-90). In particular, many mummies were donated to museums in the 19th and early 20th centuries by European and American travelers, who purchased objects from dealers in Egypt (Ikram and Dodson 1998:67-72). These dealers usually obtained their stock from local (often illicit) sources, so little information exists about any archaeological context (Sowada 2006). Assemblages and whole objects were sometimes broken up and sold to different people (e.g. Beinlich-Seeber 2006).

While a mummy and its coffin acquired from a private source make an interesting museum display, the question of their relationship raises issues about the scientific study of embalming techniques and the correct interpretation of the material for museum visitors. The dating of coffins is well understood from archaeological and art historical inquiry (Ikram and Dodson 1998 and references),

\footnotetext{
${ }^{1}$ Department of Ancient History, Macquarie University, Sydney, NSW, Australia. Corresponding author. Email:ksowada@zeta.org.au.

${ }^{2}$ Institute for Environmental Research, Australian Nuclear Science and Technology Organisation, NSW, Australia.

${ }^{3}$ Institute for Materials Engineering, Australian Nuclear Science and Technology Organisation, NSW, Australia.
} 
yet there are still gaps in our knowledge about the mummification techniques of specific eras, such as the Late period (747-332 BC) (Aufderheide 2003:245-7). Moreover, where donated material is involved, the relationship of the mummy with any associated funerary objects must be established to place related studies on a sound footing (Sowada et al. 2005).

\section{MUMMY NICHOLSON MUSEUM R28.2}

The mummy of an adult (NM R28.2) and a coffin (NM R28.1) were acquired by Sir Charles Nicholson during a trip to Egypt in 1856-1857, but little is known of its acquisition (Sowada 2006). The coffin was certainly acquired in Luxor and came originally from a burial spot in western Thebes (Taylor 2006). Inscriptions on the coffin identify the owner as Padiashaikhet, who held the titles "Father of the God" and "Beloved of the God," possibly priestly titles (Taylor 2006:283-4). The coffin dates to the 25th Dynasty, more specifically $~ 725-700 \mathrm{BC}$, based on stylistic and typological grounds (Taylor 2006). The mummy was inside the coffin when it was catalogued as a single unit in London by Joseph Bonomi in the mid-19th century (Bonomi 1858:10, nr 28); indeed, Bonomi assumed that the mummy belonged to the coffin and identified the individual as Padiashaikhet. Almost certainly, the mummy was inside the coffin when it was purchased by Nicholson in Egypt.

Under the auspices of the Nicholson Museum Mummy Research Project, NM R28.2 was examined in 1997 and 1998 using X-ray and computed tomography (CT) imaging, during which samples were also taken for DNA analysis and future research. In addition, the wrappings were examined in a preliminary study conducted by Ms Jana Jones (Macquarie University, Sydney). All the wrappings were identified as linen, which is made from fibers of the flax plant, and the most common textile used in ancient Egypt (Vogelsang-Eastwood 2000).

This research was also conducted on 2 other mummies in the collection, NM R26 and NM R27.3. The results of DNA analysis on mummy NM R27.3 revealed it to be the body of a man inside the coffin of a woman (Sowada et al. 2005). This then raised the question of whether the mummy purchased with the coffin of Padiashaikhet was actually Padiashaikhet himself. This could not be resolved on radiographic data alone; thus, textile samples from the mummy were subjected to ${ }^{14} \mathrm{C}$ dating.

\section{RADIOCARBON DATING OF LINEN}

${ }^{14} \mathrm{C}$ dating of linen has involved a variety of pretreatment methods, which are based around the acidalkali-acid (AAA) treatment, with additional treatments including a detergent or solvent wash and/ or a bleaching step.

\section{AAA Treatment with Solvent Extraction}

Variations of the AAA treatment, some combined with solvent extraction or detergent washes, were used by the Arizona, Oxford, and Zurich laboratories in the dating of 4 different linen samples including the Shroud of Turin (Damon et al. 1989). While AAA treatments varied with $\mathrm{HCl}$ and $\mathrm{NaOH}$ concentrations, and solvent extractions with different solvents (petroleum ether or ethanol) or detergents, the results were in agreement (Damon et al. 1989; Gove 1990).

Solvent extractions combined with AAA treatment have also been used to pretreat woven textile (described as cellulose, probably linen) to date an Egyptian mummy using a series of Soxhlet extractions with $\mathrm{CHCl}_{3} /$ ethanol, ethanol, and acetone followed by $10 \% \mathrm{HCl}, 1 \% \mathrm{NaOH}$, then a final $\mathrm{HCl}$ rinse (Kieser et al. 2004). 
Gove et al. (1997) performed both AAA washing and AAA combined with solvent extraction on cloth from a mummified Egyptian ibis; however, the linen results were consistently younger than that of the ibis bone. Gove et al. (1997) hypothesized that possible bioplastic coatings formed by bacterial action over time may be a source of contamination, though it was not conclusive as the difference between the linen and bone collagen also may have been from the bird's diet of fish. They proposed that the AAA combined with solvent treatment had not removed contamination from the surface of the fabric, and given the large surface area, this could be a significant source of contamination from younger carbon.

\section{AAA Treatment with Bleaching}

Housley et al. (1989) compared 2 pretreatment methods on a linen sample. One linen sample was subjected to either (a) a chloroform wash, followed by $1 \mathrm{M} \mathrm{HCl}, 0.1 \mathrm{M} \mathrm{NaOH}$, and $1 \mathrm{M} \mathrm{HCl}$ prior to bleaching with $5 \%$ chlorite at $\mathrm{pH} 3$ (this step being a standard cellulose extraction) or (b) acid (4\% $\mathrm{HCl})$ and alkali $(4 \% \mathrm{NaOH})$ treatment. The 2 treatments showed no difference in age.

\section{AAA Treatment with Solvent Extraction and Bleaching}

A combination of AAA with solvent washes and sodium chlorite bleaching has been used by the Oxford group when pretreating cellulosic materials that may be contaminated by glue (Dee et al. 2010). An oxidizing treatment had also been used by the Oxford group who performed a short bleaching step on their 4 fabric samples after the AAA treatment, using a dilute $(2.5 \%)$ solution of sodium hypochlorite, though no significant difference in ages was reported (Damon et al. 1989).

In all cases, the AAA treatment is performed, as this is a standard pretreatment method used in ${ }^{14} \mathrm{C}$ dating. This treatment was initially devised to remove carbonates, fulvic acids, and humic acids from soils, sediments, charcoal, and buried materials (Olson and Broecker 1958). Materials such as mummy linen are unlikely to require AAA treatment as contaminates such as fulvic acids and humic acids are unlikely to affect textiles that have not been buried in soil. In the case of mummy NM R28.2, there was no evidence that it had been in soils or sand, so it was decided that the alkali treatment for removal of fulvic and humic acids was not required, particularly as the alkali step may be a potential source of modern carbon contamination (Hatté et al. 2001). While there is potential for carbonate contamination resulting from the use of natron (sodium carbonate) in the embalming process (Aufderheide 2003), the acid step of the AAA treatment was also omitted as the oxidizing treatment is done at low $\mathrm{pH}(\sim \mathrm{pH} 2)$. This would be sufficient to remove traces of carbonate.

It is proposed that a series of solvent extractions to remove traces of resins, oils, and waxes along with a rigorous oxidizing treatment such as that used by Housley et al. (1989) and Dee et al. (2010) would be successful in removal of contaminants from mummy linen while retaining the cellulosic components of the original flax.

\section{METHODS}

\section{Sampling the Mummy Linen}

In September 2007, textile samples were taken from the wrappings of mummy NM R28.2 for ${ }^{14} \mathrm{C}$ dating. A human tissue sample would have been preferable (Aufderheide 2003:324), but for conservation reasons only samples of the wrappings were available. As the exterior of the mummy had been exposed for over $150 \mathrm{yr}$, textile pieces from deep within the mummy's wrappings were extracted. Around the head, the layers of linen sheets had been loosened some time in the past, and so it was possible to separate each layer down to the tightly bound head of the individual. 
To extract the samples, the exterior linen sheet was lifted to reveal the unexposed layers of linen below. Two samples were cut with a clean pair of scissors from separate sheets. Sample 1 (OZK370) was a roughly triangular linen piece $32 \mathrm{~mm} \times 56 \mathrm{~mm}$, with a sample mass of $510 \mathrm{mg}$. The sample was obtained from the proper left-hand side of the mummy, at the back of the head. The fragment was blackened in patches, probably from embalming fluids. Sample 2 (OZK371) was taken from deep within the wrappings, cut from the final inner sheet placed over the tightly bound head; the sample was cut from the sheet at the mummy's forehead on the proper right-hand side. The sheet had been hemmed in antiquity. The sample was roughly rectangular and measured $57 \mathrm{~mm} \times 44 \mathrm{~mm}$, with a mass of $865 \mathrm{mg}$.

Examination of the 2 linen samples with an optical microscope shows both fabrics appear to be clean of dirt and fungi. Sample 1 (OZK370) was the most variable in appearance, with most of the fabric appearing clean (Figure 1a,b), apart from a black patch in the center of the cloth. This black patch was examined and showed a dark matted coating on the fibers (Figure 1c,d). An area away from the black patch showed some possible contamination, which seemed more like staining of the fibers (Figure 1e). In apparently clean areas of OZK370, a small amount of contamination is only seen at high magnification, suspected to be a small fragment of resin trapped in the fibers (Figure 1f). Sample 2 (OZK371) was free of stains and appeared remarkably clean.

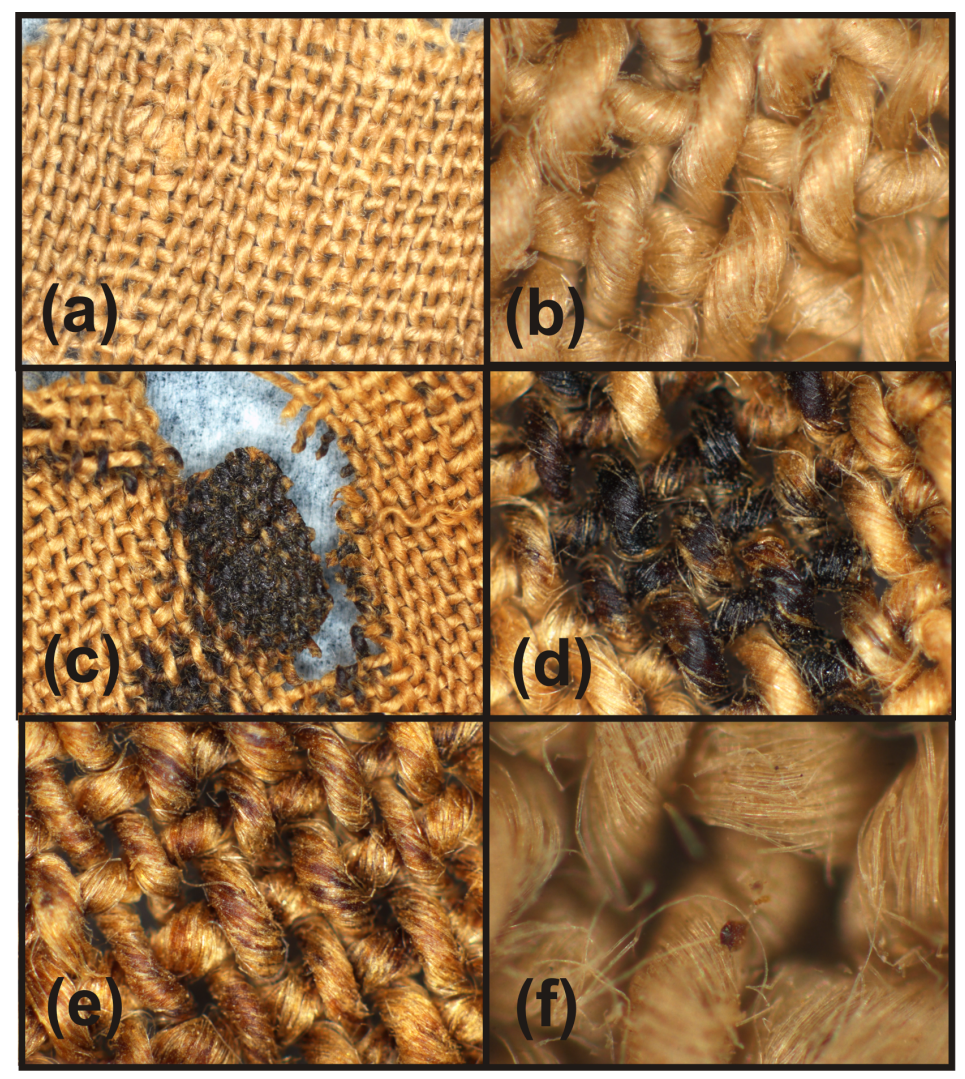

Figure 1 Linen sample OZK370 at (a) $6 \times$ magnification and (b) $22 \times$ magnification; (c) black patches at $6 \times$ magnification and (d) $22 \times$ magnification; (e) staining of linen fibers at $22 \times$ magnification; and (f) a small resin fragment in a clean area of linen at $64 \times$ magnification. 


\section{Dating}

A clean segment of each linen sample was subsampled for dating, then treated to remove contamination. While the samples were deliberately taken from inside the wrappings close to the mummy and therefore protected from external contaminants, possible contaminants include substances associated with the embalming process such as resins, oils, waxes, spices, wine, and ancient salts. Due to the nature and the uncertainty of the sources of contamination, extensive pretreatment was performed to remove contaminants. Approximately $95 \mathrm{mg}$ of fabric was removed from clean sections of the linen; these were then pretreated using an extensive series of solvent extractions followed by an oxidizing treatment used for extraction of holocellulose. Solvent extractions comprised Soxhlet extraction for 2-3 hr each with toluene, dichloromethane, methanol, and water; these were then followed by washings with diethyl ether, acetone, and finally thoroughly washed with deionized water. Holocellulose from the linen was then obtained by bleaching with $1 \%$ sodium chlorite in $\mathrm{HCl}(1 \mathrm{M})$ for $2 \mathrm{hr}$ at $80^{\circ} \mathrm{C}$; the fabric was then washed thoroughly with deionized water and dried at $60{ }^{\circ} \mathrm{C}$ (Hua et al. 2000). The appearance of the linen before and after pretreatment was examined under the microscope to determine the efficacy of the cleaning process (Figure 2).

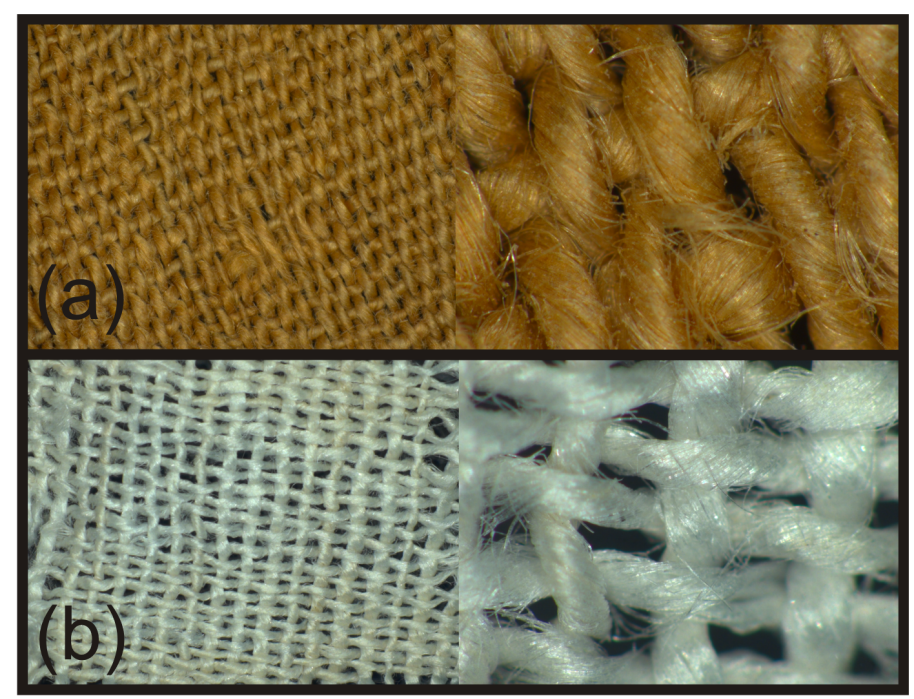

Figure 2 Linen sample OZK371 (a) before treatment at $6 \times$ and $32 \times$ magnification and (b) after pretreatment at $6 \times$ and $32 \times$ magnification.

After chemical pretreatment, these samples were processed to graphite by combustion to $\mathrm{CO}_{2}$ at $900{ }^{\circ} \mathrm{C}$ in sealed Vycor ${ }^{\mathrm{TM}}$ tubes containing $\mathrm{CuO}$ and $\mathrm{Ag}$ wire. The $\mathrm{CO}_{2}$ was converted to graphite by reduction over Fe catalyst at $600{ }^{\circ} \mathrm{C}$ using an excess of $\mathrm{H}_{2}$ (Hua et al. 2001). The resulting graphite target was pressed into aluminium cathodes and analyzed at ANSTO. The $\delta^{13} \mathrm{C}$ of the graphite was determined using an EA-IRMS (Fink et al. 2004). The ${ }^{14} \mathrm{C}$ ages have been rounded according to Stuiver and Polach (1977).

\section{RESULTS AND DISCUSSION}

The results for samples OZK370 and OZK371 show excellent agreement (Table 1). 
Table $1{ }^{14} \mathrm{C}$ dates from the linen wrappings of mummy NM R28.2.

\begin{tabular}{llllll}
\hline Lab ID & Museum nr & $\begin{array}{l}\delta^{13} \mathrm{C} \\
(\%)\end{array}$ & $\begin{array}{l}{ }^{14} \mathrm{C} \text { content } \\
\pm 1 \sigma(\mathrm{pMC})\end{array}$ & $\begin{array}{l}{ }^{14} \mathrm{C}_{\text {age }}{ }^{\mathrm{a}} \\
\pm 1 \sigma(\mathrm{BP})\end{array}$ & $\begin{array}{l}\text { Calibrated age } \\
\text { range }^{\mathrm{b}}(1 \sigma)\end{array}$ \\
\hline OZK370 & NM R28.2 Sample 1 & $-23.0 \pm 0.1$ & $78.89 \pm 0.40$ & $1905 \pm 45$ & AD 28-206 \\
OZK371 & NM R28.2 Sample 2 & $-22.8 \pm 0.1$ & $78.91 \pm 0.39$ & $1905 \pm 40$ & AD 30-135 \\
\hline
\end{tabular}

${ }^{\mathrm{a}}{ }^{4} \mathrm{C}$ ages have been rounded according to Stuiver and Polach (1977).

${ }^{b}$ The unrounded ${ }^{14} \mathrm{C}$ ages were calibrated using OxCal 4.1 (Bronk Ramsey 2009) and IntCal09 data (Reimer et al. 2009).

${ }^{14} \mathrm{C}$ ages were calibrated against the IntCal09 curve (Reimer at al. 2009) using OxCal v 4.1 (Bronk Ramsey 2009). As both samples were obtained from the same mummy, the 2 results were combined, giving an age range of cal AD 68-129 (1 $\sigma)$, which places mummy NM R28.2 in the Roman period. The probability distributions for Samples 1 and 2 and the combination of Samples 1 and 2 are shown in Figure 3.

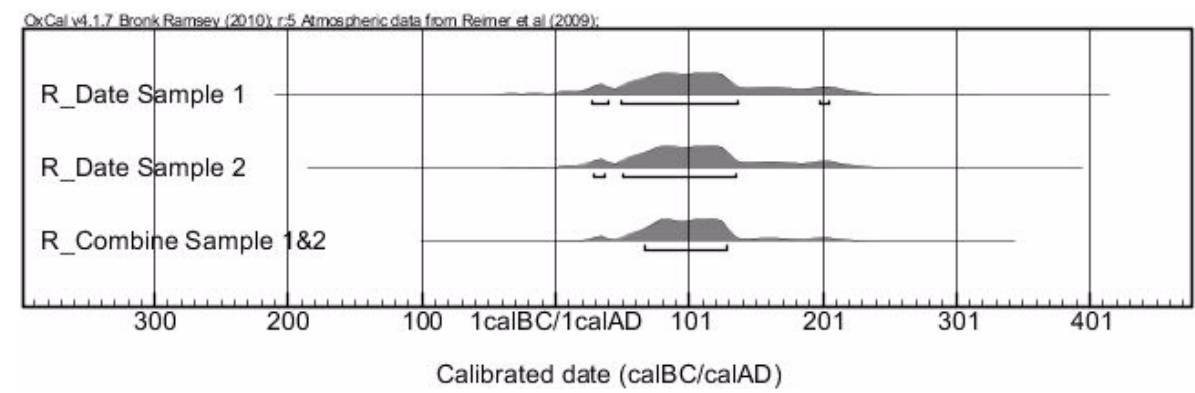

Figure 3 Probability distributions for calibrated ages for Sample 1, Sample 2 and for the combined results. Calibrations were done using OxCal v 4.1 (Bronk Ramsey 2009) and the IntCal09 data of Reimer et al. (2009).

As a way of testing the effectiveness of the pretreatment, the ages of raw, untreated fractions of both linen samples were also determined. The untreated samples gave consistent dates that were slightly older than the pretreated linen, indicating that contamination comprising older carbon had been removed. Sample 1 (OZK370) gave a ${ }^{14} \mathrm{C}$ age of $2065 \pm 30 \mathrm{BP}$, which was calibrated to $156-136 \mathrm{cal}$ BC (11.4\%) and 114-42 cal BC (56.8\%) (1 $\sigma)$. Sample 2 (OZK371) gave an age of $2075 \pm 45$ BP, or $166-44$ cal BC $(1 \sigma)$.

A date range of cal AD 68-129, indicating the Roman period, is also supported by the overall presentation of the body, which bears certain hallmarks of Roman era mummification, such as the head tilted forward with the chin resting on the chest, observed during preliminary study of the radiological images (Dawson and Gray 1968:31, BM EA 54053, pl. 34d; Filer 1997). Correspondence of the date of the wrappings with the presentation of the body helps preclude the possibility that the body was rewrapped with textiles of a completely different date, as has been observed elsewhere (Hodge and Newton 1979). If there was once any evidence of a Roman date on the external features of NM R28.2, such as a mask or painted shroud (Graefe 1997; Ikram and Dodson 1998:187-91), these have been long removed. The loosened character of the wrappings around the head probably occurred at the hand of dealers in search of amulets or other items for separate sale, or to remove a face cartonnage. No exterior ornamentation was noted by Bonomi when the mummy was catalogued in the 19 th century. 
The correspondence between the $2{ }^{14} \mathrm{C}$ dates of the linen and the appearance of the mummy as coming from the Roman era demonstrates that judicious sampling and a series of solvent extractions followed by treatment for isolation of holocellulose is a suitable method for dating linen from mummies.

\section{CONCLUSION}

${ }^{14} \mathrm{C}$ results on linen textile samples from mummy NM R28.2 confirm that it is not the body of Padiashaikhet, the owner of the coffin. Rather, it is an unnamed adult who died in the Roman period, cal AD 68-129. This date is about 750-860 yr later than the coffin. Almost certainly, dealers created an artificial ensemble of body and coffin specifically for sale, after stripping the mummy of any saleable ornaments.

These results confirm the proposition that mummies and coffins from private donors displayed in museums may not always belong together. Caution must be exercised in the study of this material and its presentation for museum display. With the date of mummy NM R28.2 now confirmed, its mummification can be studied and placed in its proper historical context. However, the name of this individual will now always remain a mystery.

\section{ACKNOWLEDGMENTS}

A grant for this analysis was obtained from the Australian Institute of Nuclear Science and Engineering in 2006 (AINGRA07/136P). Thanks also to the Sydney University Museums Conservator, Ms Alayne Alvis, for her assistance in obtaining the textiles for analysis, and to Mr Michael Turner, Senior Curator of the Nicholson Museum, for permission to take the samples. We are grateful to Dr Stephen Bourke, University of Sydney, for his helpful advice on the preparation of this article, and Dr John Taylor, Senior Assistant Keeper of the Department of Egypt and the Sudan, The British Museum, for his comments on the material.

\section{REFERENCES}

Aufderheide A. 2003. The Scientific Study of Mummies. Cambridge: Cambridge University Press.

Beinlich-Seeber C. 2006. Painted judgement scene on wood, R344. In: Sowada KN, Ockinga BG, editors. Egyptian Art in the Nicholson Museum, Sydney. Sydney: Mediterranean Archaeology. p 27-43.

Bonomi J. 1858. Egyptian and other Antiquities collected by Sir Charles Nicholson, D.C.L., LL.D. \& \& \&c. London: Reynolds and Co.

Bronk Ramsey C. 2009. Bayesian analysis of radiocarbon dates. Radiocarbon 51(1):337-60.

Cockburn A, Barraco RA, Reyman TA, Peck WH. 1975. Autopsy of an Egyptian mummy. Science 187(4182): 1155-60.

Damon PE, Donahue DJ, Gore BH, Hatheway AL, Jull AJT, Linick TW, Sercel PJ, Toolin LJ, Bronk CR, Hall ET, Hedges REM, Housley R, Law IA, Perry C, Bonani G, Trumbore S, Woelfli W, Ambers JC, Bowman SGE, Leese MN, Tite MS. 1989. Radiocarbon dating of the Shroud of Turin. Nature 337(6208):611-5.

David R, editor. 2008. Egyptian Mummies and Modern Science. Cambridge: Cambridge University Press.

Dawson WR, Gray PHK. 1968. Catalogue of Egyptian Antiquities in the British Museum I. Mummies and Human Remains. Oxford: Oxford University Press.
Dee MW, Brock F, Harris SA, Bronk Ramsey C, Shortland AJ, Higham TFG, Rowland JM. 2010. Investigating the likelihood of a reservoir offset in the radiocarbon record for ancient Egypt. Journal of Archaeological Science 37(4):687-93.

Filer J. 1997. If the face fits: a comparison of mummies and the accompanying portraits using computerised axial tomography. In: Bierbrier ML, editor. Portraits and Masks: Burial Customs in Roman Egypt. London: British Museum Press. p 121-6.

Fink D, Hotchkis M, Hua Q, Jacobsen G, Smith AM, Zoppi U, Child D, Mifsud C, van der Gaast H, Williams A, Williams M. 2004. The ANTARES AMS facility at ANSTO. Nuclear Instruments and Methods in Physics Research B 223-224:109-15.

Gove HE. 1990. Dating the Turin Shroud-an assessment. Radiocarbon 32(1):87-92.

Gove HE, Mattingly SJ, David AR, Garza-Valdes LA. 1997. A problematic source of organic contamination of linen. Nuclear Instruments and Methods in Physics Research B 123(1-4)3:504-7.

Graefe E. 1997. A mummy portrait of Antinous from Thebes. In: Bierbrier ML, editor. Portraits and Masks: Burial Customs in Roman Egypt. London: British Museum Press. p 54. 
Hatté C, Morvan J, Noury C, Paterne M. 2001. Is classical acid-alkali-acid treatment responsible for contamination? An alternative proposition. Radiocarbon 43(2A):177-82.

Hodge KC, Newton GWA. 1979. Radiocarbon dating. In: David AR, editor. Manchester Museum Mummy Project. Multidisciplinary Research on Ancient Egyptian Mummified Remains. Manchester: Manchester Museum. p 137-47.

Housley RA, Srdoč D, Horvatinčić N. 1989. AMS and radiometric dating of an Etruscan linen book and associated mummy. Radiocarbon 31(3):970-5.

Hua Q, Barbetti M, Jacobsen GE, Zoppi U, Lawson EM. 2000. Bomb radiocarbon in annual tree rings from Thailand and Australia. Nuclear Instruments and Methods in Physics Research B 172(1-4):359-65.

Hua Q, Jacobsen GE, Zoppi U, Lawson EM, Williams AA, Smith AM, McGann MJ. 2001. Progress in radiocarbon target preparation at the ANTARES AMS Centre. Radiocarbon 43(2A):275-82.

Ikram S, Dodson A. 1998. The Mummy in Ancient Egypt. Equipping the Dead for Eternity. London: Thames and Hudson.

Kieser J, Dennison J, Anson D, Doyle T, Laing R. 2004. Spiral computed tomographic study of a pre-Ptolemaic Egyptian mummy. Anthropological Science 112(1):91-6.

Olson EA, Broecker WS. 1958. Sample contamination and reliability of radiocarbon dates. Transactions of the New York Academy of Sciences Series II 20:593604.

Reimer PJ, Baillie MGL, Bard E, Bayliss A, Beck JW,
Blackwell PG, Bronk Ramsey C, Buck CE, Burr GS, Edwards RL, Friedrich M, Grootes PM, Guilderson TP, Hajdas I, Heaton TJ, Hogg AG, Hughen KA, Kaiser KF, Kromer B, McCormac FG, Manning SW, Reimer RW, Richards DA, Southon JR, Talamo S, Turney CSM, van der Plicht J, Weyhenmeyer CE. 2009. IntCal09 and Marine09 radiocarbon age calibration curves, 0-50,000 years cal BP. Radiocarbon 51(4): 1111-50.

Sowada KN. 2006. Sir Charles Nicholson: an early scholar-traveller in Egypt. In: Sowada KN, Ockinga BG, editors. Egyptian Art in the Nicholson Museum, Sydney. Sydney: Mediterranean Archaeology. p 1-13.

Sowada KN, Matheson C, Spigelman A, Spigelman M. 2005. An interloper revealed: DNA analysis and the identification of an Egyptian mummy. Bulletin of the Australian Centre for Egyptology 16:101-16.

Spencer J. 2002. The decoration of the coffin and other inscriptions. In: Dawson DP, Giles S, Ponsford MW, editors. Horemkenesi May He Live Forever! The Bristol Mummy Project. Bristol: Bristol Museums and Art Gallery. p 38-54.

Stuiver M, Polach A. 1977. Discussion: reporting of ${ }^{14} \mathrm{C}$ data. Radiocarbon 19(3):355-63.

Taylor J. 2006. The coffin of Padiashaikhet. In: Sowada KN, Ockinga BG, editors. Egyptian Art in the Nicholson Museum, Sydney. Sydney: Mediterranean Archaeology. p 263-91.

Vogelsang-Eastwood G. 2000. Textiles. In: Nicholson PT, Shaw I, editors. Ancient Egyptian Materials and Technology. Cambridge: Cambridge University Press. p 268-98. 